\title{
Cervical Cancer Pathologic Regional Lymph Nodes TNM Finding v7
}

National Cancer Institute

\section{Source}

National Cancer Institute. Cervical Cancer Pathologic Regional Lymph Nodes TNM

Finding V7. NCI Thesaurus. Code C89544.

A pathologic finding about one or more characteristics of cervical cancer, following the rules of the TNM AJCC V7 classification system as they pertain to staging of regional lymph nodes. 